TABLE II. 9 AUGUST 1981 LONGITUDINAL PROFILE OF GORNERA WATER QUALITY

$\begin{array}{ccccc}\begin{array}{c}\text { Distance from } \\ \text { portal } \\ \mathrm{m}\end{array} & \mathrm{pH} & \begin{array}{c}\text { Conductivity } \\ \mu \mathrm{S} \mathrm{cm}^{-1}\end{array} & \begin{array}{c}\text { Water temper- } \\ \text { ature } \\ { }^{\circ} \mathrm{C}\end{array} & \begin{array}{c}\text { Local } \\ \text { time } \\ \mathrm{h}\end{array} \\ & & & & \\ 0 & 7.20 & 12.4 & 1.1 & 16.14 \\ 100 & 7.48 & 9.9 & 1.3 & 16.25 \\ 200 & 7.36 & 10.4 & 1.4 & 16.33 \\ 300 & 7.35 & 9.8 & 1.4 & 16.40 \\ 400 & 7.40 & 9.1 & 1.5 & 16.46 \\ 500 & 7.39 & 9.9 & 1.5 & 16.54 \\ 600 & 7.45 & 9.4 & 0.9 & 17.02 \\ 700 & 7.25 & 9.2 & 1.3 & 17.08 \\ 900 & 7.20 & 10.2 & 1.4 & 17.16\end{array}$

Table II is interpreted to show the pro-glacial stream is already equilibrated with atmospheric $\mathrm{CO}_{2}$ before reaching the glacier portal. This profile was measured as before, on 9 August $1981\left(Q=15-17 \mathrm{~m}^{3} \mathrm{~s}^{-1}\right.$, air temperature $=8 \rightarrow{ }^{\circ} \mathrm{C}$, barometric pressure $=0.792$ bar), a partly sunny afternoon. Conductivity and $\mathrm{pH}$ are relatively constant throughout the profile. The water appears to warm generally down-stream during re-aeration, but not in a continuous manner, due to sampling different water parcels. All variables exhibit some scatter attributable to sampling different parcels of water.

I conducted the 9 August 1981 traverse by running and jumping over the boulders between sampling locations. In summer, it is unlikely one individual will be able to sample the same water parcel at many down-stream locations on a swiftly flowing, pro-glacial stream, such as the Gornera. In winter, such sampling is just possible in a steep valley by skiing. Although an inept skier, I was able to sample this way at Nisqually Glacier in 1977 and 1984. An easier approach is to use field assistants or recording instruments, if the resources are available.

I gratefully acknowledge the extensive data on longitudinal dispersion in glacial streams furnished by Professor Dr W. Ambach, prior to planning field sampling strategies.

$M C R$ Scientific,

227 Ravenhead,

RICHARD C. METCALF

Houston,

Texas 77034, U.S.A.

25 November 1985

Revised 30 December 1985

Ambach, W., and Jochum, O. 1973. Zur Dispersion im offenen Gerinne: Einfluss von Randzonen bei Glescherbächen. Zeitschrift für Gletscherkunde und Glazialgeologie, Bd. 9, Ht. 1-2, p. 181-88.

Chatwin, P.C. 1971. On the interpretation of some longitudinal dispersion experiments. Journal of Fluid Mechanics, Vol. 48, Pt. 4, p. 689-702.

Day, T.J. 1975. Longitudinal dispersion in natural channels. Water Resources Research, Vol. 11, No. 6, p. 909-18.

Fischer, H.B. 1968. Dispersion predictions in natural streams. Proceedings of the American Society of Civil Engineers. Journal of the Sanitary Engineering Division, Vol. 94, No. SA5, p. 927-43.

Gurnell, A.M., and Fenn, C.R. 1985. Spatial and temporal variations in electrical conductivity in a pro-glacial stream system. Journal of Glaciology, Vol. 31, No. 108, p. 108-14.

Halliday, D., and Resnick, R. 1966. Physics. New York, John Wiley and Sons.

Metcalf, R.C. 1984. Field pH determinations in glacial melt waters. Journal of Glaciology, Vol. 30, No. 104, p. 106-11.

Metcalf, R.C. In press. The accuracy of $\mathrm{pH}$ determinations in glacial melt waters. Zeitschrift für Gletscherkunde und Glazialgeologie.
Metcalf, R.C. Unpublished. $\mathrm{CO}_{2}$ in the melt waters of an Alpine glacier. [Ph.D. thesis, University of Manchester, 1983.]

Pickard, G.L. 1963. Descriptive physical oceanography. Oxford, Pergamon Press.

SIR,

\section{The faces of ice}

In spending a few months working at the Scott Polar Research Institute, I had the pleasure of meeting Charles Swithinbank and Hilda Richardson. In the course of explaining my purpose in Cambridge, which was to write a book on the growth and decay of ice, I took pains to disqualify myself as a glaciologist. This declaration immediately produced wistful and knowing smiles from both of them, for reasons I have since discovered. Despite some 20 years of working on various ice problems, I still had a narrow view of the glaciologist and it is evidently a widely held view. In this letter, I have been bold enough to suggest a possible remedy to this perennial perception problem.

The four main chapters of my book each deal with ice in a particular context which, upon reflection, suggests to me that the glaciological community at large may admit to a useful contextual taxonomy. Given the Society's general definition of glaciology as "the study of snow and ice", I suggest the following contextual sub-divisions:

Geo-glaciology, dealing with ice in and on the Earth: snow and glacier ice; avalanches; ice caps and ice sheets; aufeis and needle ice; permafrost; ice lenses, wedges, and other forms of ground ice.

Hydro-glaciology, dealing with ice in and on water: sea ice, icebergs; lake and river ice; ice shelves; frazil, anchor, slush, and pancake ice; ice in channels and conduits.

Aero-glaciology, dealing with ice in the air: snow, sleet, and hail; ice crystals, frost, hoar, and rain; accretion on land-, sea-, and airborne structures.

Bio-glaciology, dealing with ice in and on bio-organisms: snow and frost coatings; ice in biofluids; ice in unicellular organisms; ice in plants; ice in animals; ice in foods.

It is not difficult to construct other contexts such as astroglaciology and eco-glaciology.

If such terms were adopted, their common use would do much to identify glaciological specialists who may then possess a greater sense of their particular community. Reticence to acknowledge the glaciological label might then evaporate, as it evidently has in radio-glaciology, which is not a contextual division but an aspectual one. Again, it is not difficult to imagine other aspects: chemo-glaciology, electro-glaciology, thermo-glaciology, rheo-glaciology, and so on.

I know of no attempt to develop a taxonomy of glaciology on contextual and aspectual lines. May I suggest that an attempt to do so, through international discussion, would be more than an academic exercise. It would tell us more about ourselves, about each other, and may flood the membership department with the names of people who, like me, suddenly realize that they have been glaciologists all along.

Department of Mechanical Engineering,

University of Alberta,

G.S.H. Lock

Edmonton.

Alberta T6G $2 G 8$.

Canada

23 January 1986 